\title{
Mechanism-based isolation and structures of some anticancer active natural products
}

\author{
A.A. Leslie Gunatilaka, ${ }^{a}$ David G.I. Kingston, ${ }^{a}$ and Randall K. Johnson ${ }^{b}$ \\ aDepartment of Chemistry, Virginia Polytechnic Institute and State University, Blacksburg, \\ Virginia 24061-0212, and bSmithKline Beecham Pharmaceuticals, P.O. Box 1539, King of \\ Prussia, PA 19406-0939, U.S.A.
}

\begin{abstract}
Application of a mechanism-based anticancer bioassay employing DNA repairor recombination-deficient mutants of the yeast Saccharomyces cerevisiae for screening and subsequent bioassay-guided fractionation of bioactive higher plant and bryophyte extracts led to the isolation of a variety of natural products with potential anticancer activity. Presented herein are interesting structural features of some representative examples of natural products active in our mechanism-based bioassay and cytotoxicity assays along with structure-activity relationships of synthetic analogs of some of them.
\end{abstract}

The last decade has witnessed the evolution of anticancer natural product drug discovery research from an empirical search for general cytotoxic agents to a more mechanism-based approach. One such approach recently developed utilizes DNA repair- or recombination-deficient mutants of the yeast Saccharomyces cerevisiae (1). An important feature of many tumor cells is that they have defects in their ability to repair damage to DNA as compared with normal cells, suggesting that agents with selective toxicity towards repair-deficient cells might be potential anticancer agents. Strongly supporting this rationale is the fact that repair-deficient yeast mutants have been demonstrated to be hypersensitive to most DNA-damaging agents (2). The mechanism-based screen that we employ in our search for potential anticancer agents is based on the differential response of DNA repair-deficient and repair-proficient yeast strains to the test sample. Three major DNA repair pathways have been defined in yeast; they are known as the rad3, rad6 and rad52 pathways. The rad3 pathway is associated with excision repair, the rad6 pathway is the error-prone pathway, and rad52 is the recombinational pathway associated with repair of double-strand breaks and meiotic recombination (3). Yeasts deficient in each of these repair pathways and also having increased cell membrane permeability have been used to screen for potential anticancer agents $(1,4)$. Figure 1 depicts the principles underlying the production of these yeast mutants.

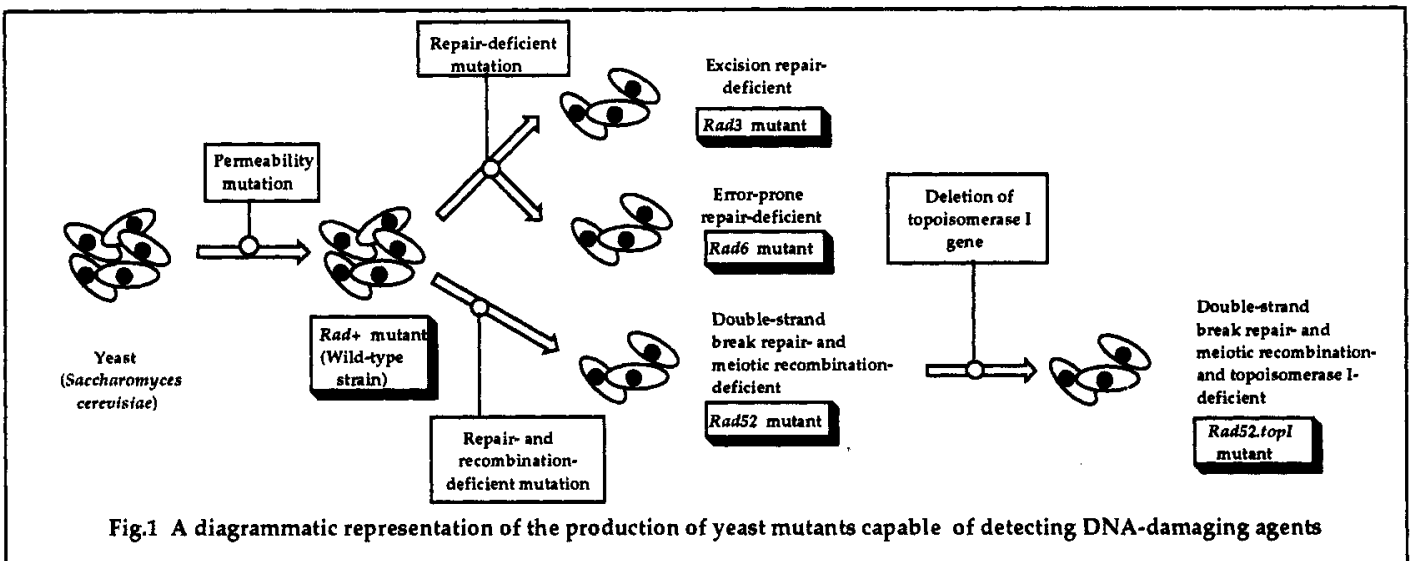

The basis of this bioassay is diagrammatically presented in Fig. 2. The assay is carried out by measuring the growth inhibition of repair-deficient yeasts, usually rad52 and rad6, in comparison with the wild-type yeast, $\mathrm{rad}+$, having the same permeability mutation (Fig. 1). A mutant lacking one of the repair pathways will be more sensitive than the wild-type yeast to DNA damage repaired predominantly 
by that pathway, and thus agents which cause DNA damage can be selectively detected. The results are usually reported as $\mathrm{IC}_{12}$ values, which represent the concentration (in $\mu \mathrm{g} / \mathrm{ml}$ ) required to produce an inhibition zone of $12 \mathrm{~mm}$ diameter around a $100 \mu \mathrm{l}$ well in the yeast strain in question. An extract is

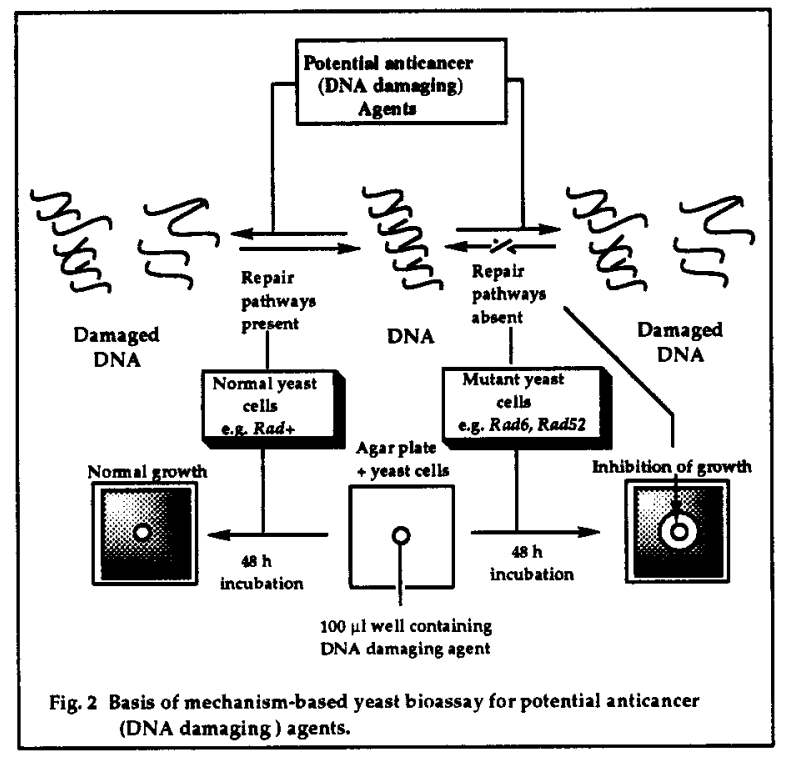
considered active if it shows selective activity against one or more repair-deficient yeasts (IC 12 less than one-third that of the wild-type yeast) and has an $\mathrm{IC}_{12}$ less than 2000. A mutant rad 52 repair-deficient strain, rad52.topI, with the additional deletion of the DNA topoisomerase I gene is also available and can detect agents that produce DNA damage specifically by interacting with DNA topoisomerase (5). Thus an agent which exhibits greater activity towards the rad52.topl strain than to the rad52 strain, with a differential of at least 3, most probably mediates its activity through inhibition of DNA topoisomerase II. Conversely, greater toxicity towards rad52 implies the presence of a DNA topoisomerase I inhibitor.

In our continuing search for potential anticancer agents from natural sources, we have employed the above mechanism-based yeast bioassay to screen over 5000 extracts derived from bryophytes and higher plants collected in the U.S. , Brazil, Ethiopia, Kenya, Philippines, and Sri Lanka. The steps involved in our search for natural product-based anticancer agents are summarized in Fig. 3. Bioactive compounds and their analogs have been subjected to cytotoxicity assays with a view to selecting candidates for further development as anticancer agents.

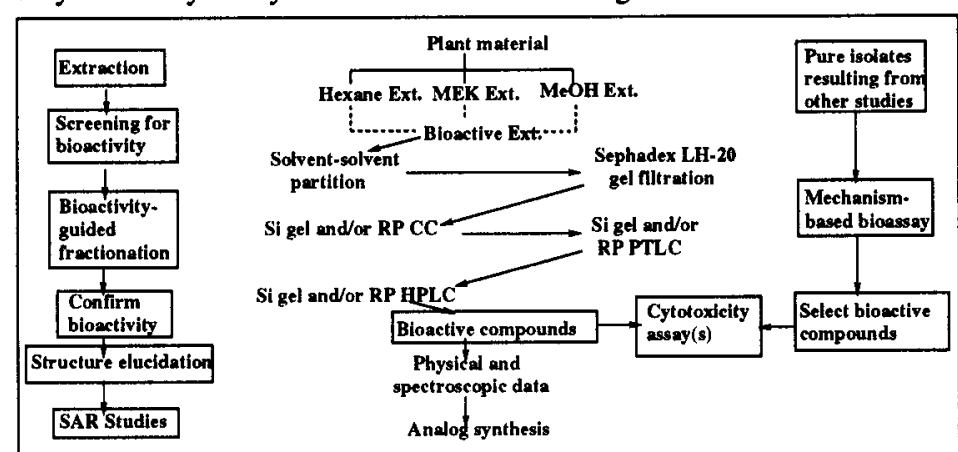

Fig. 3 Steps involved in our search for natural product-based anticancer agents.
The DNA damaging agents encountered in this study had diverse structures ranging from sterols, sesquiterpenoids, limonoids, pterocarpans, naphthoquinones, oxoaporphines, piperidines, and coumarins. Included in the following discussion are representative examples of some of these classes of compounds along with the bioactivities exhibited by them in our mechanism. based bioassay and cytotoxicity assays.

Sterols of Pseudobersama mossambicensis (Meliaceae) - Bioactivity-guided fractionation of the methyl ethyl ketone (MEK) extract of this previously uninvestigated Kenyan plant afforded 3 bioactive

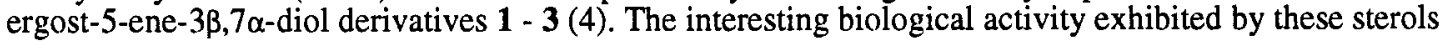

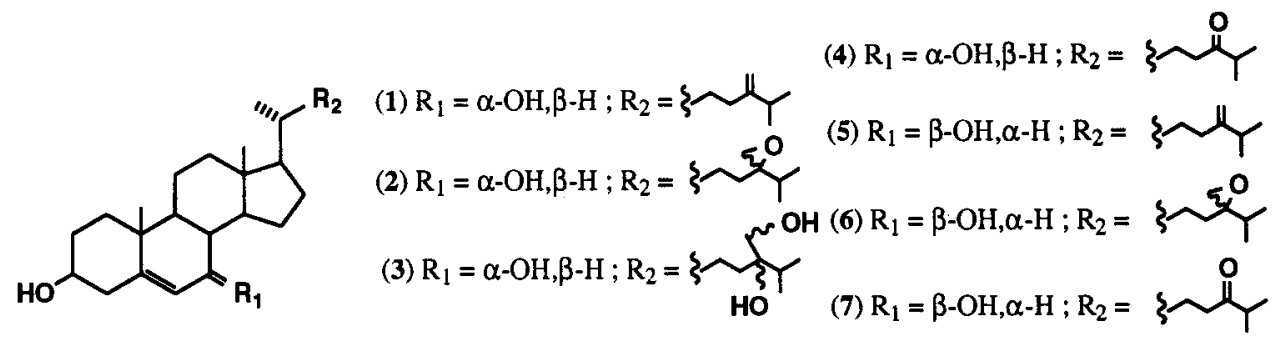

prompted us to synthesize several structural analogs $4-7$ starting from readily available stigmasterol, and the bioactivity profile of these natural and synthetic sterols is presented in Table 1 . Based on these data it can be hypothesized that there is no direct correlation between the activity shown by these sterols 
in mechanism-based and cytotoxicity bioassays. The synthetic $7 \beta$-hydroxy analogs 5 - 7, although found to be cytotoxic, showed no DNA damaging activity suggesting that they act by different mechanisms.

TABLE 1. Bioactivity of natural sterols and their semisynthetic analogs.

\begin{tabular}{|c|c|c|c|c|c|}
\hline \multirow[t]{2}{*}{ Sterol } & \multicolumn{2}{|c|}{ Bioactivity } & \multirow[t]{2}{*}{ Sterol } & \multicolumn{2}{|c|}{ Bioactivity } \\
\hline & $\begin{array}{l}\text { Mechanism-based } \\
\operatorname{rad52} \mathrm{IC}_{12}(\mu \mathrm{g} / \mathrm{ml})\end{array}$ & $\begin{array}{l}\text { Cytotoxicity } \\
\text { Vero cell IC } 50(\mu \mathrm{M})\end{array}$ & & $\begin{array}{l}\text { Mechanism-based } \\
\mathrm{rad52} \mathrm{IC}_{12}(\mu \mathrm{g} / \mathrm{ml})\end{array}$ & $\begin{array}{l}\text { Cytotoxicity } \\
\text { Vero cell IC } 50(\mu \mathrm{M})\end{array}$ \\
\hline 1 & 8.0 & 58 & 5 & $>8000$ & 31 \\
\hline 2 & 0.4 & $>100$ & 6 & $>8000$ & 16 \\
\hline 3 & 1.0 & not tested & 7 & $>500$ & 21 \\
\hline 4 & 14.0 & 10 & & & \\
\hline
\end{tabular}

Naphthoquinones of Crescentia cujete (Bignoniaceae) - A search for compounds responsible for the bioactivity of an MEK extract of this plant resulted in the isolation of seven naphthoquinones (8 - 14) (5) and two novel furofuranonaphthoquinones (15 and 16) (6), all of which were bioactive. Structural and stereochemical analysis were carried out with the aid of 2D NMR techniques (including HMBC and selective INEPT), CD measurements, and NMR analysis of Mosher esters. For bioactivity data, see Table 2. The planar nature of these naphthoquinones suggests that intercalation into DNA may be involved in their mechanism of DNA damage.

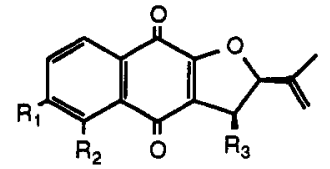

(8) $\mathrm{R}_{1}=\mathrm{R}_{2}=\mathrm{OMe} ; \mathrm{R}_{3}=\mathrm{OH}$

(9) $\mathrm{R}_{1}=\mathrm{R}_{2}=\mathrm{OMe} ; \mathrm{R}_{3}=\mathrm{H}$

(10) $R_{1}=R_{3}=H ; R_{2}=O M e$

(11) $R_{1}=R_{2}=R_{3}=H$

(12) $\mathrm{R}_{1}=\mathrm{R}_{3}=\mathrm{H} ; \mathrm{R}_{2}=\mathrm{OH}$<smiles>CC(O)c1cc2c(=O)c3cccc4c(cccc34)c(=O)c2o1</smiles>

(13) $\mathrm{R}=\mathrm{H}$

(14) $\mathrm{R}=\mathrm{OH}$<smiles>O=C1c2cccc(P)c2C(=O)c2c1oc1c(CO)coc21</smiles>

(15) $\mathrm{R}=\mathrm{H}$

(16) $\mathrm{R}=\mathrm{OH}$

TABLE 2. Bioactivity of naphthoquinines from $C$. cujete.

\begin{tabular}{|c|c|c|c|c|c|}
\hline \multirow[t]{2}{*}{ Compound } & \multicolumn{2}{|c|}{ Bioactivity } & \multirow[t]{2}{*}{ Compound } & \multicolumn{2}{|c|}{ Bioactivity } \\
\hline & 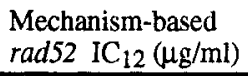 & $\begin{array}{l}\text { Cytotoxicity } \\
\text { Vero cell IC } 50(\mu \mathrm{M})\end{array}$ & & $\begin{array}{l}\text { Mechanism-based } \\
\operatorname{rad} 52 \mathrm{IC}_{12}(\mu \mathrm{g} / \mathrm{ml})\end{array}$ & $\begin{array}{l}\text { Cytotoxicity } \\
\text { Vero cell IC } 50(\mu \mathrm{M})\end{array}$ \\
\hline$\overline{8}$ & 47 & 3.7 & 13 & 14 & 0.4 \\
\hline 9 & 33 & 4.7 & 14 & 5 & 0.2 \\
\hline 10 & 48 & 4.3 & 15 & 10 & 2.3 \\
\hline 11 & 60 & not tested & 16 & 2 & 2.9 \\
\hline 12 & 80 & not tested & & & \\
\hline
\end{tabular}

Oxoaporphine alkaloids of Xylopia aethiopica and Miliusa cf. banacea (Annonaceae) - A literature search revealed the presence of diterpenes in $X$. aethiopica and no reported work on the genus<smiles>O=C1c2cc(Br)cc(P)c2-c2c(Br)c(Br)c(Br)c3ccnc1c23</smiles>

(17) $\mathrm{R}_{1}=\mathrm{R}_{2}=\mathrm{R}_{3}=\mathrm{OMe}: \mathrm{R}_{4}, \mathrm{R}_{5}=\mathrm{OCH}_{2} \mathrm{O}$

(18) $R_{1}=R_{4}=R_{5}=H ; R_{2}, R_{3}=O_{2} H_{2} O$

(19) $\mathrm{R}_{1}=\mathrm{R}_{5}=\mathrm{H} ; \mathrm{R}_{2}, \mathrm{R}_{3}=\mathrm{OCH}_{2} \mathrm{O} ; \mathrm{R}_{4}=\mathrm{OMe}$

(20) $\mathrm{R}_{1}=\mathrm{R}_{5}=\mathrm{H} ; \mathrm{R}_{2}, \mathrm{R}_{3}=\mathrm{OCH}_{2} \mathrm{O} ; \mathrm{R}_{4}=\mathrm{OH}$ Miliusa. Fractionation of the bioactive methanolic extract of $X$. aethiopica afforded the known oxoaporphine alkaloids, oxophoebine (17) and liriodenine (18), showing selective activity against rad6 and rad52 yeast mutants, and several inactive oxoaporphines. Oxophoebine was also toxic to the rad52.topI mutant. Bioassay guided fractionation of the MEK extract of $M$. cf. banacea yielded lauterine (19) and a new oxoaporphine, 10-hydroxyliriodenine (20), both with selective activity towards the rad52 and rad52.topI yeast mutants. These alkaloids represent a novel class of DNA topoisomerase inhibitors and accumulated data suggest the requirement of a methylenedioxy group for DNA damaging activity of oxoaporphines (see Table $2 a$ ).

TABLE 2a. Bioactivity of aporphine alkaloids

\begin{tabular}{cccccccc}
\hline Alkaloid & \multicolumn{3}{c}{ Bioactivity (mechanism-based) } & Alkaloid & \multicolumn{3}{c}{ Bioactivity (mechanism-based) } \\
& \multicolumn{3}{c}{$\mathrm{IC} 12(\mu \mathrm{g} / \mathrm{ml})$} & & \multicolumn{3}{c}{$\mathrm{IC}(\mu \mathrm{g} / \mathrm{ml})$} \\
\hline $\mathbf{1 7}$ & $\mathrm{rad} 52$ & $\mathrm{rad52.topI}$ & rad6 & & $\mathrm{rad} 52$ & $\mathrm{rad} 52$. topI & $\mathrm{rad} 6$ \\
$\mathbf{1 8}$ & 6.4 & 2.6 & 4.7 & $\mathbf{1 9}$ & 214 & 113 & not tested \\
\hline
\end{tabular}

Piperidine alkaloids of Cassia leptophylla (Leguminosae) - A methanolic extract of the fresh leaves of this previously uninvestigated Brazilian species afforded 3 bioactive piperidine alkaloids, spectaline (21), spectalinin (22) and canavalin (23). The bioactivity data are presented in Table 3. 
<smiles>C[C@@H]1N[C@H](P)CC[C@H]1O</smiles>

(21) $\mathrm{R}=-\left(\mathrm{CH}_{2}\right)_{12} \mathrm{COMe}$

(22) $\mathrm{R}=-\left(\mathrm{CH}_{2}\right)_{12} \mathrm{CH}(\mathrm{OH}) \mathrm{Me}$

(23) $\mathrm{R}=-\left(\mathrm{CH}_{2}\right)_{10} \mathrm{CH}(\mathrm{OH}) \mathrm{Me}$
TABLE 3. Bioactivity of piperidine alkaloids.

\begin{tabular}{ccc}
\hline Alkaloid & \multicolumn{2}{c}{ Bioactivity } \\
& $\begin{array}{cc}\text { Mechanism-based } \\
\text { rad52 } \text { IC }_{12}(\mu \mathrm{g} / \mathrm{ml})\end{array}$ & $\begin{array}{l}\text { Cytotoxicity } \\
\text { Vero cell }(\mu \mathrm{M})\end{array}$ \\
\hline $\mathbf{2 1}$ & 15 & not tested \\
$\mathbf{2 2}$ & 16 & 10.0 \\
$\mathbf{2 3}$ & 16 & 10.0 \\
\hline
\end{tabular}

Pterocarpans of Erythrina burana (Fabaceae) - From the chloroform extract of the bark of E. burana two moderately bioactive pterocarpans, phaseollidin (24) and cristacarpin (25) were isolated (7). Their bioactivity data are given in Table 4.

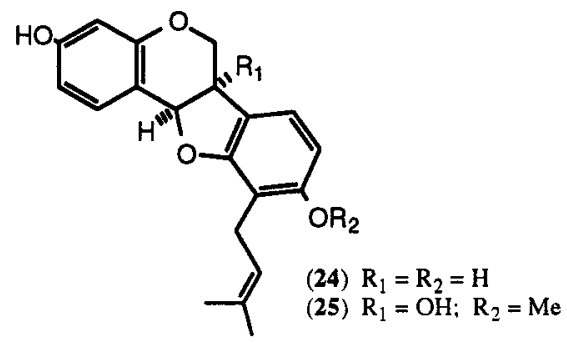

TABLE 4. Bioactivity of pterocarpans

\begin{tabular}{|c|c|c|c|c|c|}
\hline \multirow[t]{3}{*}{ Pterocarpan } & \multicolumn{4}{|c|}{ Bioactivity $^{\mathrm{a}}$} & \multirow[b]{3}{*}{ P-388 } \\
\hline & \multicolumn{2}{|c|}{$\begin{array}{l}\text { Mechanism-based } \\
\mathrm{IC}_{12}(\mu \mathrm{g} / \mathrm{ml})\end{array}$} & \multicolumn{2}{|c|}{$\begin{array}{l}\text { Cytotoxicity } \\
\mathrm{IC}_{50}(\mu \mathrm{M})\end{array}$} & \\
\hline & $\operatorname{rad52}$ & rad6 & $\mathrm{CHOC}$ & CHOC-PGO & \\
\hline 24 & 500 & $>1000$ & 4.0 & 7.6 & $>10.0$ \\
\hline 25 & 80 & 540 & $>20.0$ & 4.0 & $>10.0$ \\
\hline
\end{tabular}

Coumarins from Sri Lankan Rutaceae - In an extension to our random screening program by including pure isolates (see Fig. 3), we have evaluated 12 coumarins isolated from three Sri Lankan Rutaceae and found two of them, seselin (26) and xanthyletin (27) to be active. Seselin also exhibited moderate cytotoxicity (Table 5).<smiles>CC1(C)C=Cc2c(ccc3ccc(=O)oc23)O1</smiles>

(26)<smiles>CC1(C)C=Cc2cc3ccc(=O)oc3cc2O1</smiles>

(27)
TABLE 5. Bioactivity of coumarins

\begin{tabular}{ccc}
\hline Coumarin & \multicolumn{2}{c}{ Bioactivity } \\
& $\begin{array}{c}\text { Mechanism-based } \\
\text { rad } 52\end{array}$ & $\begin{array}{c}\text { Cytotoxicity } \\
\text { Vero cell }\end{array}$ \\
& $\mathrm{IC}_{12}(\mu \mathrm{g} / \mathrm{ml})$ & $\mathrm{IC}_{50}(\mu \mathrm{M})$ \\
\hline $\mathbf{2 6}$ & 33 & 12 \\
$\mathbf{2 7}$ & 52 & $>20$ \\
\hline
\end{tabular}

Acknowledgements This presentation would not have been possible without expert assistance from the following coworkers; Dr. A. Ahmad, Ms. N. Baj, Prof. V da S. Bolzani, Dr. G.W. Chan, Prof. E. Dagne, Mr. L. Faucette, Mr. T.E. Glass, Dr. G.G. Harrigan, Dr. C.E. Heltzel, Mr. G.A. Hofmann, Prof. J.L. Liang, Dr. Habib-ur-Rehman, Dr. G. Samaranayake and Prof. L.M.M. Valente; we gratefully acknowledge their valuable contributions to this program. The funding for this work was provided by a National Cooperative Drug Discovery Group grant (1 UO1 CA 50771) awarded to the University of Virginia (Dr. S.M. Hecht, Principal Investigator).

\section{REFERENCES}

1. R.K. Johnson, H.F. Bartus, G.A. Hofmann, J.O. Bartus, S.-M. Mong, L.F. Faucette, F.L. McCabe, A. Chan, and C.K. Mirabelli, in "In Vitro and In Vivo Models for Detection of New Antitumor Drugs." Ed. by L.J. Hanka, T. Kondo, and R.J. White, Organizing Committee of the 14th International Congress of Chemotherapy, Kyoto, p. 15-26 (1986).

2. W.-K. Eng, L. Faucette, R.K. Johnson, and R. Stenglanz, Mol. Pharmacol. 34, 775 (1988).

3. J.C. Game in: "Yeast Genetics; Fundamentals and Applied Aspects." Ed. by J.F.T. Spencer, D.M. Spencer, and A.R.W. Smith, p. 109, Springer-Verlag, New York (1983).

4. A.A.L. Gunatilaka, G. Samaranayake, D.G.I. Kingston, G. Hofmann, and R.K. Johnson J. Nat. Prod. 55, 1648 (1992).

5. C.E. Heltzel, A.A.L. Gunatilaka, T.E. Glass, D.G.I. Kingston, G. Hofmann, and R.K. Johnson, J. Nat. Prod. 56, 1500 (1993).

6. C.E. Heltzel, A.A.L. Gunatilaka, T.E. Glass, and D.G.I. Kingston, Tetrahedron 49, 6757 (1993).

7. E. Dagne, A.A.L. Gunatilaka, D.G.I. Kingston, M. Alemu, G. Hofmann, and R.K. Johnson, J. Nat. Prod. 56, 1831 (1993). 